\title{
Varieties of Capital Flows: What Do We Know?
}

Eduardo Levy Yeyati \& Jimena Zúñiga

CID Working Paper No. 296

May 2015

(c) Copyright 2015 Levy Yeyati, Eduardo; Zuniga, Jimena; and the President and Fellows of Harvard College

\section{Working Papers Center for International Development at Harvard University}




\title{
Varieties of capital flows: What do we know
}

\author{
Eduardo Levy Yeyati \\ Jimena Zúñiga ${ }^{1}$
}

May 15, 2015

\section{Introduction}

Capital flows have been the subject of key policy concern since the Brady plan launched the emerging markets asset class. Their massive volume, coupled with their volatile and procyclical nature, is often associated with a variety of financial and real risks: excess exchange rate volatility (gradual overvaluation and sharp corrections), dollar liquidity crunches, distressed asset sales, and crisis propensity.

These risks have changed over time. Emerging market crises in the 1990s and 2000s were inherently driven by financial dollarization and balance sheet effects, the latter were intimately related with capital inflows in the form of growing foreign liability positions. But, now that financial dollarization has receded in the emerging market word (either through debt deleveraging or international reserve accumulation), the focus shifted to the macroeconomic effects of cross market flows, including extended periods of exchange rate misalignment and the amplification of business cycles in a context of large and persistent terms-of-trade shocks and global liquidity swings. Hence, the difficulty of evaluating capital flows based on data mostly from the 1990s and early 2000s. Hence, also, the emphasis on the recent empirical literature that revisits the issue with fresh data and an open mind.

Capital flows cannot be addressed indistinctly or in isolation. Increasingly, academics and practitioners have flagged that different types of capital flows display different behaviors. Conventional wisdom tends to assume that, within portfolio flows, fixed income assets (bonds) are more harmful than equity in that they may introduce

\footnotetext{
${ }^{1}$ Eduardo Levy Yeyati is Visiting Professor of Public Policy at the Harvard Kennedy School of Government, and Professor at Universidad Torcuato Di Tella. Jimena Zúñiga is Professor at Universidad Torcuato Di Tella. The authors are grateful to Eduardo Borenzstein, Eduardo Fernández Arias and participants at the October 2014 IDB Financial Stability and Development Seminar in Lima, Perú, for their valuable comments and suggestions. The usual disclaimers apply.
} 
currency imbalances that may create deleterious balance sheet effects in the event of sharp exchange rate depreciation. By the same token, it is usually assumed that portfolio flows (including equity securities) are more volatile than foreign direct investment (FDI), because the latter is "sunk" in illiquid instruments that, precisely because of their illiquidity, are not prone to react to speculative motives or short-lived financial distress.

However, even this simple order of riskiness deserves some reassessment. Within debt liabilities, a distinction needs to be made between foreign and local currencydenominated instruments, at a time when foreign-currency instruments still dominate local-currency ones as emerging market investments; duration is another critical aspect to consider. Is equity "safer" than a long domestic currency bond from a macro prudential perspective?

Similarly, while FDI is generally carefully planned based on long-term business prospects and thus is bound to be fairly immune to short-term bumps, there are a priori reasons to believe that components of FDI, such as equity or inter-company loans, may be quite responsive to short-term financial conditions. Moreover, a large part of what we measure as FDI in the balance of payments (BOP) is reinvested earnings, that is, funds that never leave or enter the local economy: the flows that ultimately feed into the foreign exchange market are substantially smaller and possibly more volatile than what the BOP figures suggest.

Yet another important (and empirically tricky) distinction to be made is the residency of the investor, namely, the separate evolution of foreign assets and liabilities, as opposed to the more traditional net flows: whereas net flows seem to have become more stable and smaller over time, foreign assets and liabilities (sometimes denoted as "gross" flows in recent literature) may paint a wholly different picture, shedding some light on differential investor behavior.

Indeed, the investor class is another relevant (and, again, hard to document) dimension to refine the capital flow discussion. Inward and outward flows by residents may respond in different ways from those of non-residents. Among the latter, large institutional (mostly passive) investors may pursue different strategies (and be more prone to herding) than retail investors or hedge funds, resulting in various degrees of responsiveness to economic and financial determinants, local and global. In particular, the deepening of benchmarking practices, most notably through the proliferation of index and exchange traded funds, adds to the technical cross-country comovement in assets prices and, as a result, to the exposure to exogenous shocks. 
It is in this context that central banks in the developing world have started to monitor capital flows in a more detailed way, a process that requires gathering information of higher degree of granularity and developing more specific analyses of the determinants and sensitivities of different types of flows. Only recently, the literature on the determinants and riskiness of capital flows has made progress by focusing on more detailed data. But this progress is still underway, and recent research is still mainly based on broad (accrual-base) BOP data, or on very partial, privately compiled subsamples like those tracked by EPFR.

Data are also critical to evaluate the convenience and merit of alternative responses to capital flows. Traditional macroeconomic tools, such as the interest rates or foreign exchange intervention, are not free from adverse collateral costs. Given the procyclicality of most capital flows, the use of interest rates (e.g., through unsterilized interventions) to counter flows would subordinate monetary policy like in the textbook case of a currency peg, implying lower rates in good times and higher rates in bad times, and amplifying the underlying shocks. Meanwhile, sterilized Intervention, if at all effective, would place the central bank at the other end of the speculative flow, accumulating reserves in an inverted carry trade position and potentially incurring in a sizeable quasi fiscal cost if interest rate differentials are wide, or if appreciation pressures turn out to be persistent rather than cyclical. And it is yet to be seen whether micro economic prudential measures aimed at reducing the sensitivity of the financial sector to capital flows (the so-called "macro prudential" approach) are indeed effective in reducing both the financial vulnerability and the volume of speculative flows.

Ultimately, the policy response, both from a normative and a positive standpoint, is notably difficult to evaluate in general terms: the scarcity of data to characterize the varied nature of capital flows combines with a number of country-specific aspects (e.g., equilibrium real interest rate, financial dollarization, exchange rate pass through, quality of financial supervision, terms-of-trade volatility, trade and financial openness, labor flexibility) and externalities (e.g., effects on financial intermediation or monetary policy) that cannot be ignored.

Moreover, a meaningful characterization is not independent from the policy question at hand. Why do we care about flows? Is it the precautionary concern about a sudden flow reversal and its impact on the financial capacity of dollarized debtors, be it governments, banks, or corporations? Is it the business cycle concern about the procyclicality of flows that may tighten the external constraint creating a hard-to- 
reverse current account deficit (thereby inflating expansions at the expense of deepening downturns)? Is it the monetary concern of a destabilizing pass through to prices? Is it the growth concern about excessive overvaluation and its Dutch diseasetype persistent impact on exports and import substitution and thereby on employment and economic activity? Is it the risk of asset overvaluation and bubbles that may end, belatedly, in financial stress?

No survey, let alone a specific research paper, can give all these aspects the attention they deserve. In this paper, we work selectively to review the recent empirical work on capital flows, to illuminate the main messages and policy implications of this ongoing debate as it presently stands, and to identify areas where evidence is inconclusive or scarce and further research is needed.

\section{Varieties of Capital Flows: Stylized facts}

A large and growing body of literature has concerned itself with the effects of "flows" and the rationale for policy responses. Why are capital flows so often regarded as a concern? Magud, Reinhart and Rogoff (2011) classify the motives eliciting action against capital flows into four fears: fear of appreciation, fear of "hot money", fear of large inflows (and the asset price bubbles they can entail), and fear of loss of monetary authority. Binici et al (2009), similarly, highlight flows are disliked because they may cause exchange rate pressures, hot money, and a loss of the monetary tools. Fratzscher (2012) lists four motives for the use of capital controls: "an FX policy objective; a capital flow management goal; a financial stability aim; and a macroeconomic policy objective".

In turn, De la Torre, Didier and Pienknagura (2012) note that the inherent volatility of capital flows may bring instability and uncertainty with permanent adverse effects on income, and amplified business cycles and crises (Kaminsky and Reinhart, 1999). The procyclicality of capital flows, they add, may also have a perverse effect on macroeconomic stability: "consumption and spending might grow excessively during periods of capital flow bonanza and they might have to adjust drastically when foreign capital stops flowing in"; in particular, "the lack of access to world capital markets during bad times may also hamper the ability of governments to conduct countercyclical fiscal policies (Kaminsky, Reinhart and Vegh, 2005; Reinhart and Reinhart, 2008)".

Some papers go a step further, attempting to provide more insight regarding these motives or the hierarchy among them. Fratzcscher (2012), for example, finds that the FX policy objective and concerns about an overheating of the domestic economy have been 
the two main motives for policies of capital controls. Malloy (2013), using a panel least squares model with AR1 residuals and heteroskedasticity-corrected standard errors (White) for 15 EM cross-sections and monthly data from 2001 to 2012, finds that the competitiveness motive is a determinant for foreign exchange rate intervention, alongside short-run smoothing and precautionary motives. Aizenman, Hutchison and Noy (2008) add that the concern over real exchange rate stabilization in commodityintensive countries appears to be related to adverse real output effects associated with real exchange rate volatility. And a large body of recent literature goes deeper into analyzing the potential effects of flows on the nominal or real FX and their real-economy consequences as a motivation for policy action. ${ }^{2}$

This literature, large as it is, often analyzes flows in a generic way. A differentiated approach that distinguishes by type of flow or by type of investor is comparatively much more rare. Luckily, recent research has started to fill in this gap. The renewed interest on the capital flows triggered by the global financial crisis of 2008-2009 has been accompanied by a more specific focus on the composition and differential behavior of capital flows, as a first step to refine the normative analysis of the associated concerns as well as the more practical discussion on what policy response works better in each case.

Some flows, conventional wisdom tells us, are more risky than others. In general, FDI is assumed to be good and more stable, while portfolio flows are assumed to be more volatile -particularly debt, as opposed to equity, flows. Ostry et al (2010), for example, propose the following decreasing order of riskiness for capital flows (with short-term instruments riskier than long-term ones within each category): foreign-currency debt, local-currency debt (with CPI-linkers being riskier than nominal bonds; no mention of interest-rate linkers), portfolio equity investment, and foreign direct investment. As a rationale, they argue that debt liabilities (especially in foreign exchange) imply fixed obligations for the borrower, with more limited risk sharing with the creditor. "FDI, especially greenfield FDI (our italics), is not only less likely to flee in a crisis, it may also be a source of additional financing", they add, although no evidence is presented on the latter.

\footnotetext{
${ }^{2}$ See, e.g., Adler and Tovar (2011), BIS (2014), Levy-Yeyati (2010), Potines and Rajan (2011), De la Torre, Levy Yeyati and Pienknagura (2013), Caballero and Lorenzoni (2009), Lane (2013), and Aizenman, Hutchison and Noy (2011). On the potential effects of flows on macroeconomic and financial stability as the rationale for policy responses, see Korineck (2011), Jacome, Nier and Imam (2012), Obstfeld, Shambaugh and Taylor (2008), Gourinchas and Obstfeld (2011), Calvo, Izquierdo and Loo-Kung (2012), Berkmen et al. (2009).
} 
The emphasis on currency risk has long been shared by most experts in the capital flow literature. However, the rationale to place inflation linkers above equity in the risk ranking is debatable. For example, the credit risk of CPI linkers is bound to be minor in low inflation economies as it eludes both currency and interest rate risk. In particular, under some version of inflation targeting, CPI indexation should limit the variability of the debt ratios (that is, the ratio of debt service to the issuer's payment capacity, as proxied by the GDP). Moreover, the impact of a capital flow reversal on the exchange rate is related to the low degree of currency hedging by the foreign investors: as foreign investors unwind their local position they buy back the foreign currency and add to the depreciation pressure. Thus, if foreign participation in the equity market exceeds that in local fixed income markets (as is usually the case when local bonds are largely held by domestic banks and institutional investors), then equity may end up being more volatile than fixed income.

In addition, the view of equity financing and, in particular, FDI as a more stable and reliable source of external finance may be subject to some definition and measurement problems when the data are sourced, as is customary, on accrual basis from the BOP. Finally, the reflection of capital flows on overvaluation and current account reversals, while present in all three cases, differs significantly in nature according to the investor base.

In what follows, we survey the empirical literature that addresses the distinction between different types of capital flows focusing on their variety in terms of vehicle (as in portfolio versus FDI flows) as well as source (as in resident versus nonresident investors). More specifically, we order the analysis according to the following distinctive cuts:

\section{- Vehicle:}

- Currency risk: foreign versus local currency assets, where the latter are immune to the currency exposure and balance-sheet effects that characterized emerging market crises until the early 2000s;

○ Risk sharing: fixed versus variable income assets, where the latter allow for greater risk sharing between creditor and debtor and therefore reduce the financial exposure of the recipient country (and increases that of the funding country);

- Liquidity risk (duration): short-term versus long-term debt, where the latter would in principle be more sensitive to fundamentals;

\section{- Source:}


○ Residency: Non-resident versus resident flows, namely, the distinction between changes in net foreign assets and liabilities as recorded in the BOP, usually denoted in the literature as "gross flows", which in principle should behave and affect local macroeconomic stability differently: priors about their relative riskiness are not straightforward in this case;

- Management: passively versus actively managed flows, where the former tend to be more sensitive to external shocks that affect either the benchmarks or global liquidity (as in the case of the synchronized redemptions and correlated liquidations during the 2008-2009 global crisis) and the latter tend to be generally more volatile.

Following this, we zoom in two distinctive kinds of flows that call for a separate look: FDI and bank flows.

\section{Currency: Foreign versus local currency assets}

The balance-sheet problem, namely, the fact that excessive foreign currencydenominated fixed income external finance creates a currency mismatch somewhere in the economy (lending banks, borrowing firms and governments), has been a tenet of emerging market crises in the 1980s and 1990s. However, most of the more recent empirical work relying on BOP data to assess the effects of capital flows on growth performance and other macroeconomic variables, particularly during the global financial crisis, fail to distinguish between local and foreign currency (let alone inflation- or FXlinked) debt liabilities. The emphasis on currency denomination may have waned because the development of local markets over the past decade has allowed many emerging economies to attract foreign capital to local currency instruments, which have tended to dominate the traditional emerging market credit class (foreign currency external debt) since the mid-2000s.

Among the few recent works revisiting the currency issue and the degree to which foreign currency debt continues to entail financial risk, Dell'Erba, Hausmann and Panizza (2013) show that the currency composition of debt matters because it amplifies the sensitivity of sovereign spreads to debt ratios: they show that the correlation between debt levels and spreads in emerging markets is not statistically significant in countries where most public debt is local-currency denominated. Along the same lines, Hausmann and Panizza (2010) update their measure of original sin (defined as the inability to issue long-term sovereign debt in the national currency) to look at the "redemption 
hypothesis" (namely, the fact that many emerging economies actually could issue longterm local-currency-denominated bonds in the 2000s) and acknowledge a decline in "original sin" in the developing world, although partial and limited to a few emerging economies. Moreover, they do not find evidence that foreign investors are more willing to take currency risk by increasing their exposure to domestic currency bonds traded in local markets, ${ }^{3}$ although this may to some extent reflect legal concerns (a preference for external-law instruments that is also reflected in the "jurisdiction premium", which penalizes local-law over external-law foreign-currency instruments). At any rate, they remain skeptical and argue the reason why emerging economies could conduct countercyclical policies in the 2000s is related to debt deleveraging, not redemption.

Du and Schreger (2013) provide additional support to the notion that currency matters: based on 10 emerging economies over the period 2005 to 2011, they document that local currency sovereign spreads are much smaller than the corresponding foreign currency spreads (and more correlated with global risk factors, in particular, with the risk-off rally in the midst of the 2008-2009 global crisis), ${ }^{4}$ in line with the longstanding view that sovereign credit risk is largely associated with dollar liquidity shortage in the presence of foreign currency debt.

More generally, Bordo, Stuckler and Meissner (2010), updating a long literature on financial dollarization and crisis propensity, document that greater ratios of foreign currency debt to total debt are associated with increased risks of currency and debt crises, although the strength of the association depends crucially on a country's net debt (in particular, the value of its reserves) and its policy credibility. ${ }^{5}$ And while the risks of external financial dollarization may have become less prevalent as developing economies stabilize and develop local capital markets, they may still be relevant, in a more convoluted way, in countries that are (or prepare to be) part of a monetary unions as pointed out by Dell'Erba, Hausmann and Panizza (2013), Corsetti (2010) and De Grauwe's (2011).

\footnotetext{
3 "Mexico is often quoted as an example of a country that has been able to place a large amount of longterm domestic-currency bonds with US investors, and yet less than 17 percent of Mexican bonds held by US investors are denominated in Mexican pesos. These data [from the US Treasury data on the composition of the bond portfolio of US investors] suggest that US investors remain unwilling to take currency risk."

${ }^{4}$ They estimate the local currency credit spread as the spread of local currency bonds over the synthetic local currency risk-free rate constructed using cross currency swaps. Accordingly, they also find that local currency spreads are less correlated across countries than foreign currency spreads.

${ }^{5}$ More specifically, "the risks of crisis are the greatest when borrowing in foreign currency is rapid and large, banking systems are prone to crisis, and international reserves are low"
} 
In sum, while the recent literature continues to flag foreign currency debt as potentially the most deleterious vehicle for capital inflows, the currency issue appears to have gone down a few positions in the list of concerns in the capital flow debate, a reflection of the decreasing importance of foreign currency debt as a channel for capital flows in the emerging world. However, it remains a key issue in financially less sophisticated countries in the developing world, as well as in economies with no national currency or in the process to join a currency union.

\section{Risk sharing: Fixed (debt) versus variable income (equity) assets}

In theory, bond flows are riskier than equity liabilities because the latter entail greater risk-sharing by investors. Some studies assess the risk differential of these flows by exploring the relationship between countries' liability structures and variables such as growth performance, crisis propensity, or output and inflation volatility. For example, Ostry et al (2010) use OLS regression analysis to compare growth resilience (defined as average growth in 2003-07 minus average growth in 2008-09) against the structure of foreign liabilities (stocks, in percent of GDP, as of end-2007) - financial FDI, nonfinancial FDI, debt, and equity. Debt liabilities are found to have a negative and statistically significant effect on growth performance during the crisis, while the coefficients for equity liabilities did not turn out statistically significant in most of the specifications.

In turn, Catão and Milesi-Ferretti (2013), explore the question of whether the composition of external assets and liabilities matters for risk propensity. ${ }^{6}$ Using a discrete variable (probit) model of crisis events on the components of the net external foreign liability position (debt, portfolio equity, FDI, reserve assets) based on a sample of 70 countries (of which 41 are emerging), they find that crises become more likely as the composition of NFL is tilted toward debt, while the effects of portfolio equity liabilities seem generally weaker and not statistically significant. Along the same lines, Joyce (2010) studies the probability of a banking crisis in a sample of 20 emerging markets over the period of 1976-2002. He finds that foreign debt liabilities (as a percentage of GDP) raise the probability of a crisis, while portfolio equity flows do not have a statistically significant effect. And Ahrend and Goujard (2012) also find a robust association between the likelihood of banking crises and the stock of foreign debt liabilities in emerging economies. However, Gourinchas and Obstfeld (2012) do not find

\footnotetext{
${ }^{6}$ Crises are defined as encompassing defaults and rescheduling events, as per the definition of Bein and Calomiris, 2001 coupled with Standard \& Poors, as compiled in Borensztein and Panizza, 2008, and updated by the authors.
} 
any association between the share of external debt in total external liabilities and the probability of banking crises in emerging markets (although they do in high-income countries).

Relying on a SVAR approach, IADB (2014) (Chapter 5 and Appendix E) analyzes the impact of gross equity inflows (that is, net flows from non-residents into the local equity market) on growth in five Latin American countries and finds that "a one standard deviation fall (our italics) in these gross capital inflows may lead to a loss in GDP ranging from $1 \%$ in Colombia to almost $5 \%$ in Peru, with the other larger Latin American and Caribbean economies in between". However, as the authors admit, their analysis is somewhat partial for not considering the substitution of flows across vehicles (in particular, bank flows) or the repatriation of capital from residents (a reversal of what the literature often denotes as gross outflows). While reverse causality from output drops to equity declines is implicitly addressed by lagging equity flows, one needs to bear in mind that sophisticated equity markets tend to correlate with growth forecasts rather than current growth rates, in which case, barring growth surprises, reversed correlation between today's equities and tomorrow's growth is to be expected.

Powell and Tavella (2012) obtain a similar result in their analysis of the probability of a banking crisis: when breaking up portfolio flows into debt and equity flows, the former comes up statistically significant (albeit weakly) while the latter does not. Neither variable appears to do a good job in explaining the probability of a recession, though. However, in his own work on banking crises Caballero $(2012)^{7}$ finds that portfolio equity flows are the only type that exhibits a robust independent association with crises in the absence of a lending boom. ${ }^{8}$ In both cases, the findings are subject to the caveat that portfolio flows were in many cases quite small prior to the Brady plans of the early 1990s, and that equity flows to emerging markets only started to pick up in the early 2000s.

\footnotetext{
${ }^{7}$ Caballero (2012) explores the relationship between various types of capital flows and the probability of a banking crisis looking at 113 crisis events from 141 countries in the period 1973-2008 based on a regression analysis of a binary outcome model. First, he finds that an intense bonanza increases the probability of a crisis to 16 percent in the absence of a lending boom and to 42 percent if a lending boom is underway (from an unconditional probability of 4.4 percent). Decomposing flows into FDI, portfolioequity, and debt flows, he finds that all types of inflows, even FDI, are associated with a higher crisis probability, with the effect being mainly through a simultaneous lending boom.

${ }^{8}$ An intense bonanza in portfolio equity flows is associated with a $30 \%$ probability of a crisis in the absence of a lending boom, and a $48 \%$ probability of a crisis when there is also a lending boom. When the sample is restricted to developing countries his results are qualitatively similar: in the absence of a lending boom, a bonanza in portfolio-equity flows raises the odds of a crisis by 10 times, and by 20 times if a boom is underway.
} 
Forbes and Warnock (2012) provide yet another piece of evidence on the fickleness of debt flows (including bank flows), as opposed to equity flows (including FDI). Relying on quarterly data on gross inflows and gross outflows 1980 through 2009 in over 50 emerging and developed countries, and focusing on extreme capital flow movements that they call "waves" (more on this below), they find that most such waves are debt led episodes as opposed to equity led episodes ${ }^{9}$. They also find debt episodes to be associated with global risk aversion (as measured by the VXO), a measure of contagion, and domestic growth trends, whereas equity-led episodes appear more idiosyncratic.

Using more recent data and a different angle, De la Torre, Didier and Pienknagura (2012) highlight that investors started pulling out earlier (and more strongly) from emerging market bond funds than from emerging market equity funds in the run-up to the 2008-2009 global financial crisis, ${ }^{10}$ and suggest that the pattern may be linked to the different nature of equity and bond assets, particularly with respect to liquidity. They cite Holmstrom (2012) to argue that equity market liquidity thrives in heterogeneous beliefs about the value of the stocks, whereas the liquidity in bond markets relies from a sort of shared understanding of the underlying value of the assets; and claim this difference may have been behind the more severe response of bond funds during the crisis. However, there is an alternative, more immediate explanation at hand for the different response of bonds vs. equity funds between July 2007 and July 2008: it may simply reflect the fact that fund managers were paying attention to macroeconomic conditions, and stayed invested in equities while growth continued to surprise on the upside, while shorting bonds in the midst of inflationary concerns, especially in emerging markets where rising global food prices were at the time bringing inflation above target and forcing central banks to hike interest rates. Indeed, the converse occurred in Latin America in 2011: equities collapsed as growth slowed down, while flows rotated to bonds in anticipation of interest cuts. At any rate, the different behavior of bond and equity dedicated mutual funds, if any, still deserves a closer look.

\section{Duration: short-term versus long-term debt}

\footnotetext{
${ }^{9}$ In particular, "80\% of inflow episodes (surges and stops) and $70 \%$ of outflow episodes (flights and retrenchments) - are fueled by debt, not equity, flows"

10 In particular, "there were large redemptions from emerging bond funds between July 2007 and July 2008 (of about 16.1 percentage points of initial assets), while emerging equity funds had positive injections during the same period (of about 5.8 percentage points of initial assets)".
} 
Few of the above studies incorporate maturity considerations into their empirical works. Blanchard, Faruquee and Das (2010) analyze, among other things, the role of short term external debt (as a percentage of GDP) in explaining unexpected growth during the most acute semester of the global financial crisis, Q4 2008 to Q1 2009, in 29 emerging economies, and find a strong relationship. In a multivariate regression, they find shortterm debt to be always strongly significant. ${ }^{11}$ In contrast, total foreign liabilities (as a percentage of GDP, also in 2007) do not turn out significant when added to the baseline regression and leave the short-term debt coefficient unaffected. Finally, an interaction between short-term debt and the exchange rate regime suggests that the negative effect of short-term debt may have been stronger in countries with fixed exchange regimes. $^{12}$

Lane and Milesi-Ferreti (2010) look at the growth deceleration in 2008-2009 relative to the boom period 2005-2007 as a function of variables related to gross and net external exposure as of end-2007: the level of financial openness, the net position vis-à-vis BISreporting banks, the net foreign asset position, the level of short-term external debt, and the stock of foreign exchange reserves, in addition to other standard controls. They choose thresholds to identify countries most severely affected by the crisis (40 countries). Next, they select thresholds that single out the same number of countries in the sample whose growth performance has been strongest, and compare the mean and median values of several macroeconomic and financial variables across the two samples. For emerging and developing countries, they find that countries with higher short-term debt as a ratio of reserves experienced sharper output and demand declines. This result also holds when excluding low-income countries and financial centers from the samples.

On a related theme, in their work on external financing variables and policy choices, Aizenman, Chinn, and Ito $(2009)^{13}$ find that short-term debt (as well as total debt

${ }^{11}$ A cross country regression between the two variables yields an $\mathrm{R} 2$ of 0.41 and entails that an increase of 10 percentage points in the ratio of short-term debt to GDP is associated with a 3.3 percentage point decline in growth (at an annual rate). The authors highlight their results to be consistent with that of earlier literature linking debt and growth, particularly Patillo, Poirson, and Ricci (2002), who study the incidence of the total debt ratio on growth.

${ }^{12}$ The authors caution that adding an interaction term to a 29-country cross section regression may be spreading the data too thin.

${ }^{13}$ Aizenman, Chinn, and Ito (2009) examine the effects of external financing on output volatility and inflation, in combination with the policy choices of the trilemma (exchange rate stability, monetary independence and financial integration) for a dataset of 171 countries between 1970 and 2006. They consider net FDI inflows, net portfolio inflows, and net 'other' inflows, which mostly consists of bank lending, all as a percentage of GDP; short-term debt (as a share of external debt); and total debt service (as a percentage of $\mathrm{GNI}$ ). 
service) are positive and statistically significant contributors to the level of inflation, which they attribute to countries' tendency to monetize their debt, especially under flexible exchange rate regimes with autonomous monetary policy.

\section{Residency: "Gross" vs. "net" flows}

One of the most interesting aspects of the recent literature on capital flows is the shift in focus away from the vehicle and toward the source. In particular, a number of papers have started to address the different behavior of flows according to the invertors' origin and management type.

The first group of papers studies a distinction that is something of a misnomer: "gross" (as opposed to "net") flows as recorded in the BOP. As a reminder, gross flows typically refer to changes in the "net" local asset position of non-residents (BOP's "gross" inflows, which gets reported in the line "liabilities" and can be positive or negative) and changes in the "net" foreign asset position of residents (BOP's "gross" outflows, reported in the line "assets"). Net flows, in turn, refer to the difference between the BOP's gross inflows and outflows.

Besides this semantic confusion, though, lies an important distinction that relates to some of the aspects of the vehicles emphasized above. For example, one would expect that financial securities display a "home currency bias": non-resident investors, inasmuch as they measure real returns in their own currency, should prefer foreign currency denominated assets that minimize currency risk, whereas the opposite, ceteris paribus, should be expected from residents (Levy Yeyati, 2005). Similarly, non-residents are more likely to channel external shocks, such as a global liquidity shortage at the source country that leads to liquidations at the host (with a reversal of gross inflows more than offsetting the reversal of gross outflows, and driving net outflows), whereas resident holders are likely to react to local real shocks (with a deepening of gross outflows adding to the reversal of gross inflows to accelerate net outflows).

Several of the studies cited above (Ostry et al, 2010, Aizenman, Chinn, and Ito, 2009) focus on the net balance of each flow type. Catão and Milesi-Ferretti (2013) do consider the breakdown of gross positions in their work on the impact on the liability structure 
on crisis risk, but they focus on stocks rather than flows to conclude that net external debt is the more relevant metric for crisis risk. ${ }^{14}$

However, the distinction by residency deserves a closer look. De la Torre, Didier and Pienknagura (2012) highlight that the patterns of financial globalization, particularly as regards the evolution of "gross" and "net" capital flows, have changed dramatically in the last two decades. While the difference between the two was negligible in the 1980s, since the early 1990s residents have augmented their investments abroad, so that gross flows are now much larger than net flows.

As Cavallo et al. (2013) point out, the academic literature on capital flows has tended to focus on contemporaneous concerns: capital flight in the 1980s, capital account reversals (sudden stops in net flows) that required a current account adjustment in the 1990s and early 2000s, and, in the aftermath of the 2008-2009 global financial crisis, "gross" flows. The authors develop a new taxonomy of seven "sudden stop" types (considering whether they are associated with gross or net inflows or outflows, and combinations thereof) and assess their impact on growth and the real exchange rate. Although they find, again, that sudden stops in net flows are the most disruptive, they find that sudden stops are most damaging when driven by reversals in gross inflows, for which they admit they do not have an explanation. ${ }^{15}$

Forbes and Warnock (2011) distinguish by residency as well as they try to explain what causes extreme movements of capital flows, which they call "waves", in particular, "surge", "stop", "flight", or "retrenchment" episodes. They find that certain factors (e.g., global risk) are behind all types of episodes, whereas other things can drive some episodes but not others; for example, global growth affects the probability that countries will experience surges or stops, but has no effect on the probability that countries will experience flights or retrenchments. They identify more extreme episodes when focusing on gross as opposed to net capital flows, speaking for some cancelling-off effect between the two at times.

On a similar note, Blanchard, de Carvalho Filho and Adler (2014) highlight the potentially stabilizing role of local investors in financially integrated economies. In a study of whether sterilized FX interventions help to insulate countries from exchange

\footnotetext{
${ }^{14}$ Powell and Tavella (2012) consider gross inflows to model the probability of a banking crisis and a recession, but their focus is not on the gross vs. net distinction.

${ }^{15}$ Chapter 5 (Appendix E) of IADB (2014) provides some evidence that gross equity inflows matter for growth, albeit this evidence can be considered inconclusive given that the authors do not consider other flow types or net flows.
} 
rate pressures, they highlight that domestic investors can be good substitutes for central bank intervention, with respect to global flow shocks, because local investors naturally take opposite positions to those of foreign investors. At any rate, the different behavior of investors remains an aspect worth exploring in further research.

\section{Management: Passively versus actively managed flows}

A final aspect that helps shed light on the degree of riskiness of different flows is how those flows are managed. De la Torre, Didier and Pienknagura (2012) emphasize "the rising role of the international asset management industry (particularly mutual funds, pension funds, and hedge funds) [...] as the main conduit for cross-border portfolio capital movements". They note that "this type of capital market-based (as opposed to bank-based) flows has not added to financial stability-as many had initially hoped-but has rather led to an amplified pro-cyclicality of financial flows to emerging markets". They attribute this to "a complex set of incentives that tilts international financial intermediation towards a herd behavior that is focused on short-term horizons and where being able to exit rapidly from emerging market exposures dominates over patient analysis of long-term prospects."

The description above conflates two things. The first one has to do with fund managers' short-term horizon, which is in turn the reflection of the "liquidity" illusion of being able to pull out at the last minute -or, even worse, the result of information asymmetries between managers and investors that allows managers to download risk in time at the expense of uninformed investors. The second one has to do with the difference between passively and actively managed funds and, in particular, the role of benchmarking, that is, the measurement of performance against an asset class benchmark that characterizes passive managers.

Raddatz and Schmuckler (2012) zoom in on how mutual fund investors and managers behave and transmit shocks across countries, as opposed to playing a stabilizing role. Using portfolio weights and assets invested in each country around the world for 1,076 equity and bond mutual funds during 15 years, they show that mutual fund investments fluctuate substantially ${ }^{16}$ and pro-cyclically ${ }^{17}$, with both investors and managers

\footnotetext{
${ }^{16}$ More precisely, "the median growth rate of assets across equity funds fluctuates between $-30 \%$ and $20 \%$, with an average of $0.35 \%$ and a standard deviation of $7.44 \%$ over time" and the median growth rate of assets across bond funds fluctuates between $-20 \%$ and $10 \%$ with an average of $1.09 \%$ and a standard deviation of $3.70 \%$.
} 
retrenching from countries in bad times and investing more in good times.

In turn, Raddatz and Schmuckler (2011) examine in on the phenomenon of herding, in particular among pension funds. Analyzing monthly data from Chile during a 10-year period, they find that pension funds do herd, that is, they tend to buy/sell the same assets simultaneously. This is probably due to a "benchmarking effect", first documented in Levy Yeyati and Williams (2013), that makes the manager myopic and less sensitive to fundamentals. In their paper they show that country weights in international dedicated funds tend to remain close to their benchmarks and, as a result, the distribution of fund flows in and out of the countries in the benchmark replicates those stable weights. In particular, large redemptions (as in the sell off after the fall of Lehman Brothers in late 2008 and early 2009) induce sales and price responses that are tightly correlated across otherwise unrelated emerging economies, strengthening cross market correlation.

Raddatz, Schmuckler and Williams (2014) elaborate on this benchmarking effect examining the allocations of multi-country equity and bond funds and find that a one percent increase in a country's benchmark weight results on average in a 0.7 percent increase in the weight of that country for the typical mutual fund that follows that benchmark. While explicitly-indexing mutual funds follow the benchmark almost one-toone, the benchmark effect explains almost 50 percent of the allocations of most active funds.

Opazo, Raddatz, and Schmuckler (2014) highlight that the development of an institutional investor base does not necessarily guarantee the development of a longterm debt market. Relying on asset-level time series of portfolio holdings of mediumand long-term bond mutual funds, pension funds, and insurance companies in Chile, they document that both mutual funds and pension funds hold a large fraction of shortterm instruments, whereas insurance companies are more tilted toward the long term. ${ }^{18}$ They present evidence supporting the notion that the short-term orientation of institutional investors is likely motivated by risk management (they do invest long term in less volatile indexed instruments) and the incentive structure (particularly short-term monitoring by investors/regulators, which does not affect insurance companies).

\footnotetext{
${ }^{17}$ Fore example, a global crisis or a $10 \%$ decline in fund returns reduces injections by one percentage point in the case of equity funds. Regarding allocation across countries, "a crisis results in a $2 \%$ decline in the weights assigned to the affected country, on top of the decline implied by the relative returns"

${ }^{18}$ In particular, mutual funds and pension funds hold portfolios with an average maturity of 3.97 and 4.36 years, respectively, whereas insurance companies hold portfolios with an average maturity of 9.77 years.
} 
The above speaks for a problem that is counter-intuitive in agency problems: more monitoring by the principal pushes the agent to less efficient behavior. However, traditionally less monitoring by the principal results in more (and likely excessive) risktaking. As Raddatz and Schmuckler (2012) put it, "to the extent that open-end structures constrain long-term arbitrage, there could be socially excessive open-ending and it might be desirable to have more closed-end instruments. However, open-end funds provide more room for investors to monitor managers and avoid moral hazard problems, implying a difficult trade-off between monitoring and long-term investments".

\section{FDI: long term, illiquid, local currency, variable income flows}

Foreign direct investment flows conflate all the characteristics of a benign inflow: they are typically long term investments, in illiquid real assets, and with variable income. As such, they are often welcome as a good flow vehicle as opposed to riskier portfolio and bank flows. Is that always the case? The literature tends to agree, although with some caveats.

Cardarelli, Elekdag y Kose (2009) identify episodes of large net private capital inflows to a comprehensive sample of advanced and developing countries using a consistent set of criteria: 109 episodes to 52 countries over the period 1987-2007, of which 87 episodes were completed by 2006. They conclude: "The end of the inflow episodes typically entailed a sharp reversal of non-FDI flows while FDI proved much more resilient".

Figure 1: Financial account in Latin America and Asia (\% of GDP) 

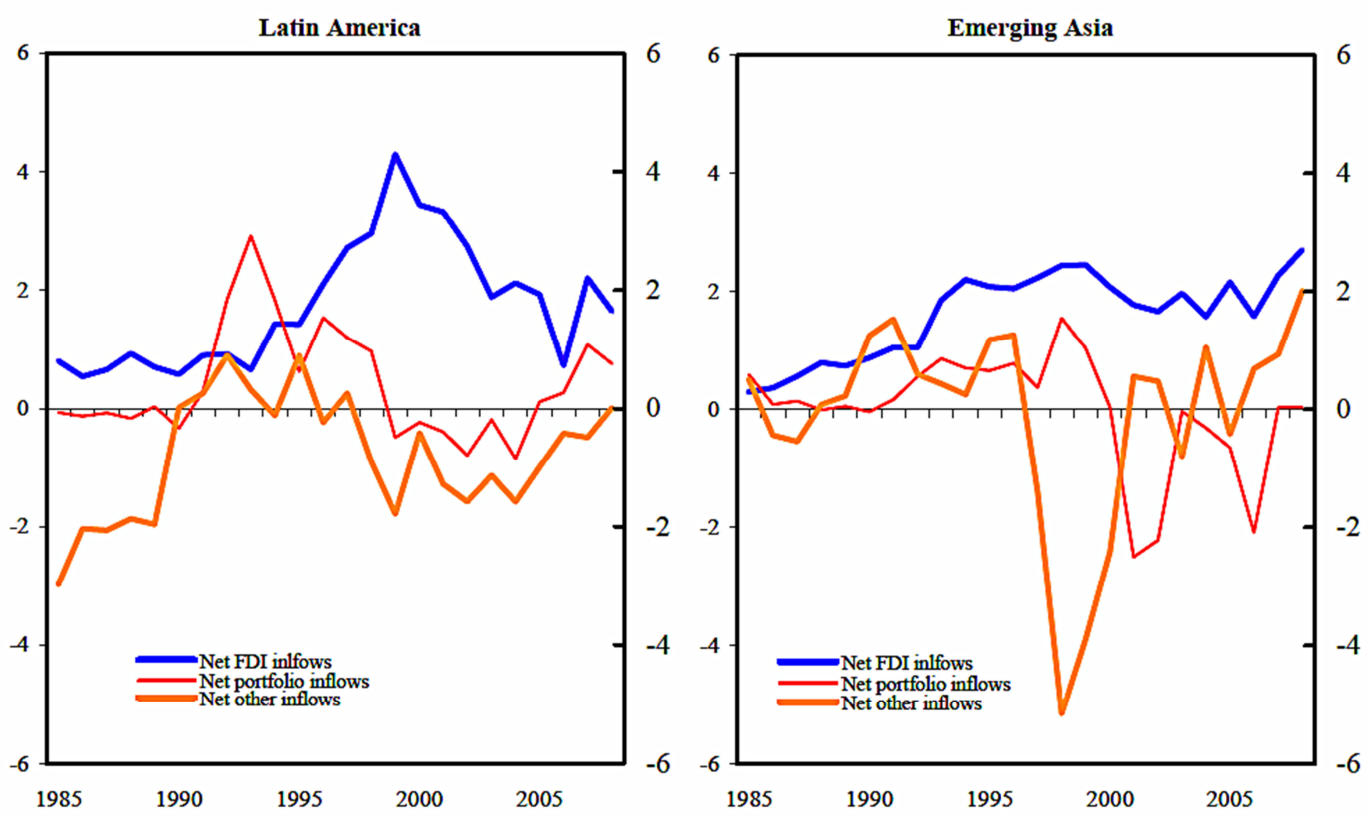

Source: Cardarelli, Elekdag y Kose (2009)

Similarly, Ostry et al (2010)'s work linking the countries' liability structure with growth performance provides some empirical support to the fact that, on average, countries with larger stocks of debt liabilities fared worse (i.e., they suffered a bigger growth slowdown), while countries with non-financial FDI fared better. The coefficients for financial FDI and equity liabilities did not turn out statistically significant in most of the specifications. ${ }^{19}$ With a similar methodology, using OLS regressions against a set of variables of financial integration and financial and external vulnerabilities, Berglof et al. (2009) analyze the effects of the global financial crisis on growth in emerging Europe in particular and in a broader sample of countries; FDI does not come out statistically significant as a predictor of growth decline.

In turn, in their work linking liability structure and crisis propensity, Catão and MilesiFerretti (2013) find that, when controlling for an increase in net liability exposure (as

${ }^{19}$ Interestingly, they argue that debt and some components of financial FDI are more risky because they are strongly associated with credit booms and foreign-exchange-denominated lending by the domestic banking system, which in turn is associated with greater vulnerability. But their results contradict their priors, since they find that the greater crisis vulnerability associated with debt liabilities holds even when controlling for credit booms and foreign-exchange-denominated lending. The authors argue that this may be because households and firms borrow directly from abroad or because flows are intermediated through nonbank financial institutions. Another possible reason would be that the 2008-2009 output drop was less due to financial shortages than to a global demand (and, as a result, trade) collapse, which is only partially captured by the trade-weighted external demand the authors include in their set of controls. If so, past flows may have had less to do with output drops than with export and import elasticities. 
measured by the current account balance), higher net FDI liabilities tend to be associated with lower crisis risk. And Joyce (2010) also finds that foreign direct investment is associated with a lower probability of a banking crisis. However, as mentioned earlier, Caballero (2012) finds that all types of inflows, even FDI, are associated with a higher crisis probability.

Finally, on the differential effect of FDI versus other flows on other variables of interest, Aizenman, Chinn, and Ito (2009) find that net FDI inflows tend to dampen output volatility in financially integrated economies. ${ }^{20}$ And Combes, Plane and Kinda (2011) find that portfolio investment flows have the largest appreciation effect, about seven times greater than that of FDI or banking flows -possibly because FDI often is used to finance imports, which offsets the final effect on the foreign exchange market.

While the empirical literature tends to support the "safe FDI inflows" view, the evidence is subject to a potentially important caveat: BOP data is based on accrual basis; more specifically, cash flows are usually overstated because figures include reinvestments. This is particularly relevant for the typically illiquid FDI flows: a large share of what shows up as inflow in the financial account is indeed reinvested earnings that never leave nor enter the country. Actual cash flows, then, are likely to be significantly smaller and possibly more volatile. Unfortunately, there is little data on cash FDI -an important pending assignment in the data collection department. Figures 1 and 2 below illustrate the point for a few Latin American countries for which CEPAL estimates disaggregated FDI numbers (the numbers are expressed as GDP ratios).

Figure 1: Composition of FDI in selected Latin American economies (\% of GDP)

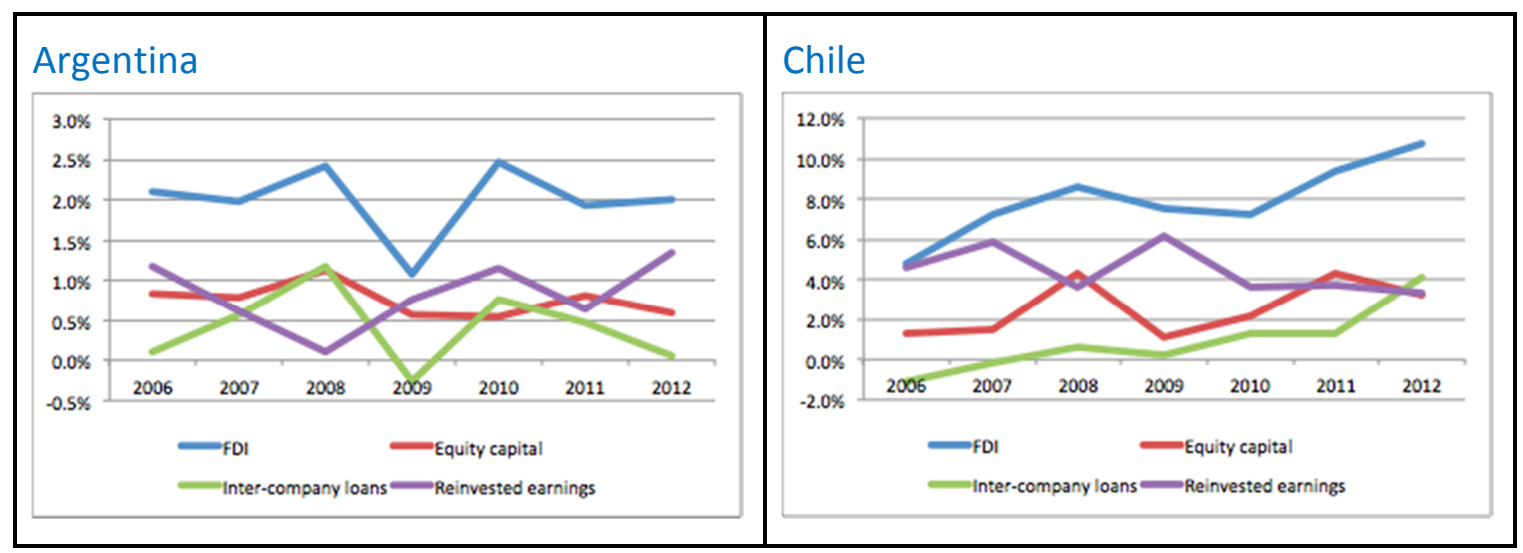

\footnotetext{
${ }^{20}$ By contrast, net portfolio inflows have a positive impact on output volatility under fixed exchange rate regimes and net other inflows (i.e. bank lending) is generally volatility increasing.
} 


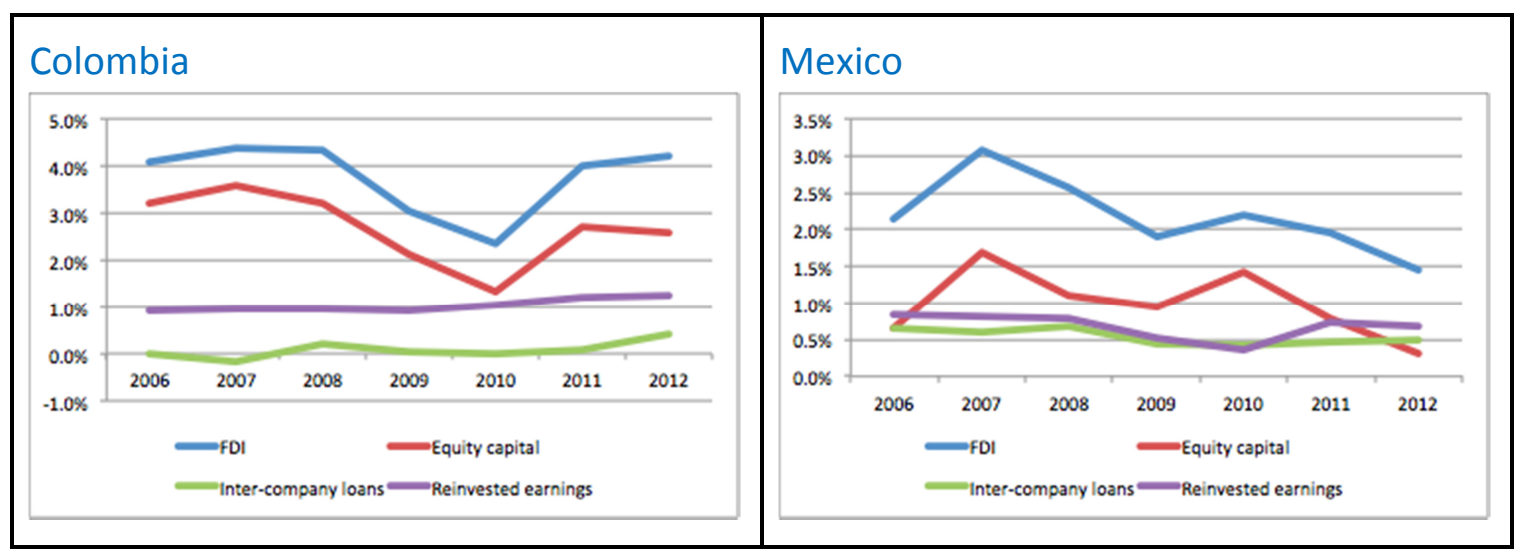

Source: CEPAL

Figure 2: Capital flows in selected Latin American economies (\% of GDP)

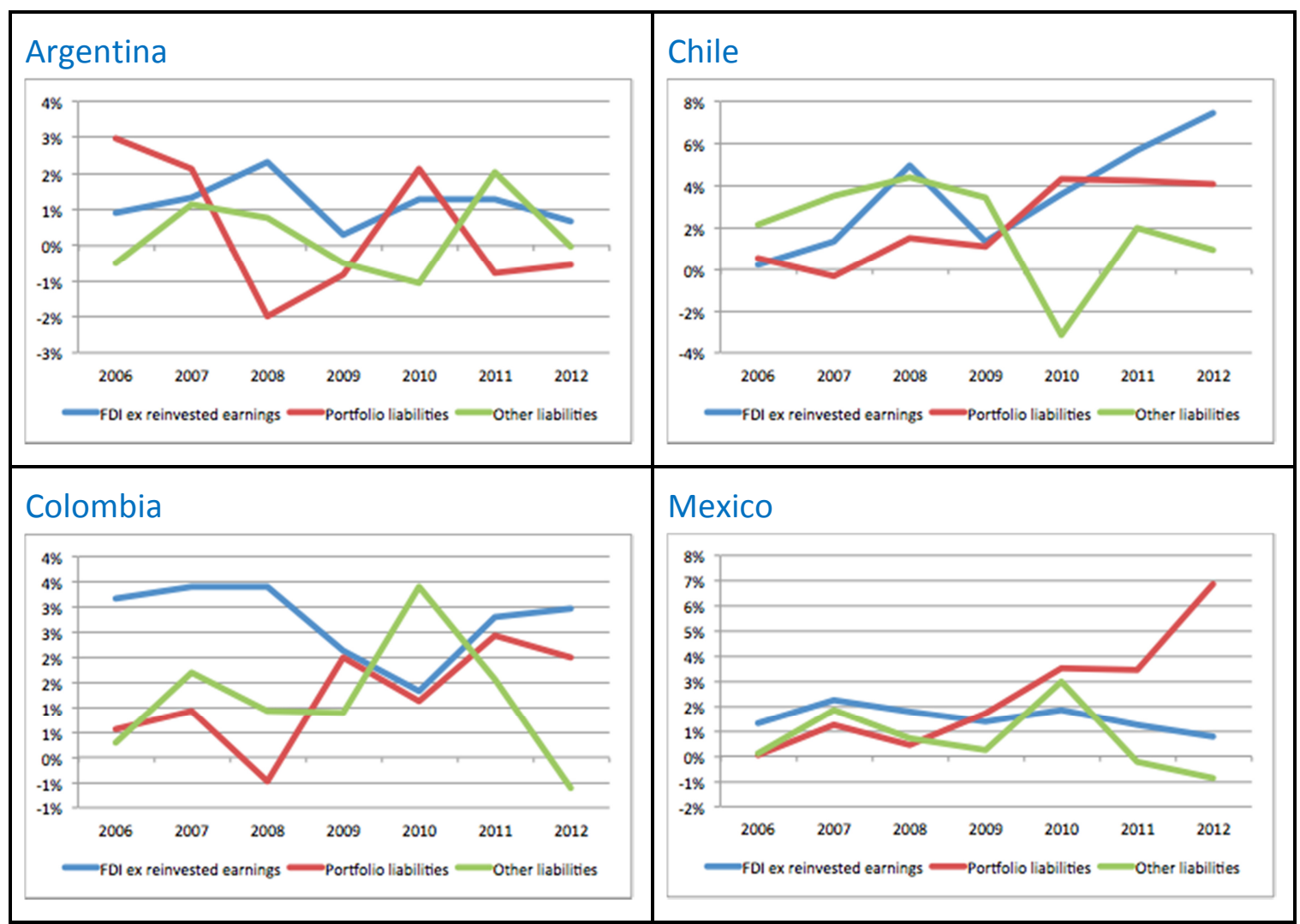

Source: CEPAL

Moreover, both FDI and some of its components can be as volatile as portfolio flows. ${ }^{21}$ For example, the standard deviation of inter-company loans in Chile, at $1.5 \%$ of GDP,

${ }^{21}$ Ostry et al (2010) also caution that some foreign direct investment (FDI) flows may be less safe than usually thought because "some items recorded as financial sector FDI may be disguising a buildup in intragroup debt in the financial sector and will thus be more akin to debt in terms of riskiness". 
exceeds that of portfolio debt liabilities. And in many cases "other liabilities" (largely foreign bank lending) is more volatile than both. At any rate, the results based on actual cash flows by type may yield a different order of riskiness and remains a pending research assignment.

Figure 3: FDI, portfolio inflows, and other inflows.

\begin{tabular}{ccccc}
\hline $\begin{array}{l}\text { Standard deviation } \\
\text { (\% of GDP) }\end{array}$ & Argentina & Chile & Colombia & Mexico \\
\hline FDI & $0.4 \%$ & $1.7 \%$ & $0.7 \%$ & $0.5 \%$ \\
\hline Equity capital & $0.2 \%$ & $1.3 \%$ & $0.7 \%$ & $0.4 \%$ \\
\hline Inter-company loans & $0.5 \%$ & $1.5 \%$ & $0.2 \%$ & $0.1 \%$ \\
\hline Reinvested earnings & $0.4 \%$ & $1.1 \%$ & $0.1 \%$ & $0.2 \%$ \\
\hline Portfolio liabilities & $1.8 \%$ & $1.8 \%$ & $0.9 \%$ & $2.2 \%$ \\
\hline Equity & $0.7 \%$ & $0.4 \%$ & $0.3 \%$ & $\ldots$ \\
\hline Debt & $1.4 \%$ & $1.2 \%$ & $1.0 \%$ & $2.0 \%$ \\
\hline Other liabilities & $1.0 \%$ & $2.3 \%$ & $1.2 \%$ & $1.2 \%$ \\
\hline
\end{tabular}

Source: CEPAL

\section{The odd man out: Foreign bank lending}

Within external debt liabilities, it may be relevant to zoom in beyond bonds, as the portion denoted as "other flows" in the BOP, consisting mostly of foreign bank lending, is empirically quite volatile. How does that map in terms of riskiness? The scorecard throws mixed results on this front.

As Blanchard, Faruquee and Das (2010) point out, whether bank debt is more or less risky is, a priori, ambiguous. Some have argued that, given the problems in advanced economies, foreign bank debt was a source of capital outflows contributing to the depth of the global financial crisis in emerging markets. Other argue that it plays a stabilizing role. The authors examine this as part of their empirical work on growth performance during the crisis, decomposing short-term debt into that owed to foreign banks (that is, banks reporting to the Bank for International Settlements) and that owed to foreign 
nonbanks, both expressed as a ratio to GDP in 2007. They find both coefficients to be negative and significant, albeit the coefficient for bank debt was less negative. The authors suggest that, other things equal, "it was indeed an advantage to have a higher proportion of bank debt." In their case study of Latvia, they also point out that foreign banks largely maintained their exposure, more so than other foreign investors and depositors. In the same vein, Berglof et al. (2009) argue that foreign bank ownership helped mitigate bank-related outflows during Q4 08 and Q1 09 in their sample of emerging European countries; however, they caution that since foreign banks contributed to credit booms and external debt accumulation in Eastern Europe-vulnerabilities associated with weaker growth performance during the crisis--the overall effect of financial integration appears to be mixed.

Berkmen et al. (2009) also study, among other determinants of growth resilience during the crisis, the stock of bank lending from advanced economies (relative to GDP). They use cross-country regressions with growth performance in 2009 compared with precrisis forecasts for that year as dependent variable, in a sample of 43 emerging economies, and a sample for 126 emerging market countries and low income countries. Interestingly, lending from advanced economies did not enter significantly in the emerging sample although a larger stock of lending from advanced countries did seem to contribute to a more severe downward revision of the growth forecast in the second sample.

However, in their work relating growth performance during the crisis and pre-crisis macroeconomic and financial variables, Lane and Milesi-Ferreti (2010) run a second set of comparisons excluding low-income countries and financial centers from their sample. In this case a number of variables related to net external vulnerabilities show significant differences between the countries most severely hit during the crisis and those of best growth performance, including the net external position, and the net position vis-à-vis BIS banks. And IMF (2010) also finds the consolidated stock of claims of BIS reporting banks (immediate borrower basis) on emerging economies in percent of their GDP as of December 2007 to be one of the metrics that best explains the cross-country variation in output collapse during the 2008-2009 global financial crisis.

Some of the papers mentioned in previous sections also assess the effect of foreign bank lending on certain variables of interest. Aizenman, Chinn, and Ito (2009), when looking at this flow type (the bulk of "net other inflows" in their dataset), found it to increase output volatility. Similarly, Powell and Tavella (2012) suggest that bank inflows help explain the probability of a banking crisis though not so much that of a recession 
and not across all specifications. And, Cavallo et al. (2013) find that sudden stops driven by bank flows are particularly disruptive.

The comparability of results is not straightforward because of the changing sample and financing structure. It is easy to understand why long samples may capture a link between bank loans and crises in the early years, when banks represented the larger part of external finances and debt defaults such as those in the 1980s were essentially on bank loans. More recently, the adverse effect of over indebtedness with foreign banks in Eastern Europe was likely a source of financial exposure in many cases. By contrast, foreign bank borrowing likely played a limited role in Latin American and Asia. As a result, while the findings of papers based on long samples and those focusing on the impact of the global crisis may coincide, they may be explaining different phenomena -or phenomena that are relevant to one region but not to the other. As we argue in the final section, our understanding of capital flows have increased over the years; at the same time, as the review above indicates, the mixture of alternative approaches (the choice of capital flow classification as well as the period and country coverage) produced a variety of results (of which Table 1 offers a stylized summary) that may benefit from some updating and refinement.

Table 1: The state of the arts

\begin{tabular}{|c|c|c|}
\hline Claim & Leaning "Yes" & Leaning "No" or inconclusive \\
\hline $\begin{array}{l}\text { FX-denominated } \\
\text { liabilities are still a } \\
\text { threat }\end{array}$ & $\begin{array}{l}\text { - FX debt is associated with increased risks } \\
\text { of currency and debt crisis (Bordo, } \\
\text { Stuckler and Meissner, 2010) } \\
\text { - Redemption from original sin is } \\
\text { incomplete (Hausmann and Panizza, } \\
\text { 2010) } \\
\text { - FX-linked debt amplifies the effect of } \\
\text { debt levels on debt spreads (Dell'Erba, } \\
\text { Hausmann and Panizza, } 2013 \text { ) } \\
\text { - Local currency sovereign spreads much } \\
\text { smaller and less correlated than } \\
\text { corresponding foreign currency spreads } \\
\text { Du and Schreger (2013) } \\
\text { Hard currency debt is a risk for countries } \\
\text { who join a monetary union (Dell'Erba, } \\
\text { Hausmann and Panizza, 2013, Corsetti, } \\
\text { 2010, and De Grauwe, 2011) }\end{array}$ & \\
\hline
\end{tabular}




\begin{tabular}{|c|c|c|}
\hline $\begin{array}{l}\text { Debt flows riskier } \\
\text { than equity flows }\end{array}$ & $\begin{array}{l}\text { - Debt liabilities have a negative and } \\
\text { significant effect on growth while equity } \\
\text { liabilities did not come out statistically } \\
\text { significant (Ostry et al, 2010) } \\
\text { - Debt liabilities increase de probability of } \\
\text { a banking crisis while equity liabilities do } \\
\text { not come out significant (Catão and } \\
\text { Milesi-Ferretti, 2013; } \underline{\text { Joyce, } 2010 ;} \\
\text { Ahrend and Goujard, 2012) } \\
\text { Debt flows increase the probability of a } \\
\text { banking crisis while equity flows do not } \\
\text { (Powell and Tavella, 2012) } \\
\text { - Extreme flow movements more linked to } \\
\text { debt than equity flows (Forbes and } \\
\text { Warnock, 2012) } \\
\text { Redemptions from bond funds greater } \\
\text { than from equity funds in run-up to the } \\
2008 \text { crisis (De la Torre, Didier and } \\
\underline{\text { Pienknagura, 2012) albeit this could be }} \\
\text { due to macroeconomic rationale. }\end{array}$ & $\begin{array}{l}\text { - No association between the } \\
\text { share of debt in the external } \\
\text { liability structure and banking } \\
\text { crisis risk (Gourinchas and } \\
\text { Obstfeld, 2012) } \\
\text { - Drop in gross equity flows } \\
\text { hurts growth (IADB, 2014) } \\
\text { - Neither variable appears to do } \\
\text { a good job in explaining the } \\
\text { probability of a recession } \\
\text { (Powell and Tavella, 2012) } \\
\text { - An intense bonanza in } \\
\text { portfolio equity flows is } \\
\text { associated with a higher } \\
\text { probability of a banking crisis, } \\
\text { especially when there is also a } \\
\text { lending boom (Caballero, } \\
\text { 2012) }\end{array}$ \\
\hline $\begin{array}{l}\text { Beware of short- } \\
\text { term debt! }\end{array}$ & $\begin{array}{l}\text { - Short term debt positively and } \\
\text { significantly associated with inflation } \\
\text { (Aizenman, Chinn, and Ito, 2009) } \\
\text { - Strong relationship between short-term } \\
\text { debt and unexpected growth decline } \\
\text { (Blanchard, Faruquee and Das, 2010) } \\
\text { and actual growth and demand declines } \\
\text { (Lane and Milesi-Ferreti, 2010) during } \\
\text { the 2008-2009 crisis }\end{array}$ & \\
\hline Residency matters & $\begin{array}{l}\text { - Gross flows now much larger than net } \\
\text { flows, hence it is important to look at } \\
\text { them (De la Torre, Didier and } \\
\text { Pienknagura, 2012) } \\
\text { - Stronger response of GDP to a sudden } \\
\text { stop in inflows (by foreign investors) vis- } \\
\text { a-vis a sudden stop in outflows (by } \\
\text { residents) (Cavallo et al., } 2013 \text { and IADB, } \\
\text { 2014) } \\
\text { Some cancelling off between inflows and } \\
\text { outflows (Forbes and Warnock, 2012; } \\
\text { Blanchard, de Carvalho Filho and Adler, } \\
\text { 2014) }\end{array}$ & $\begin{array}{l}\text { - Net flows is the metric } \\
\text { relevant for crisis risk (Catão } \\
\text { and Milesi-Ferretti, 2013) }\end{array}$ \\
\hline
\end{tabular}




\begin{tabular}{|c|c|c|}
\hline $\begin{array}{l}\text { Management type } \\
\text { matters }\end{array}$ & 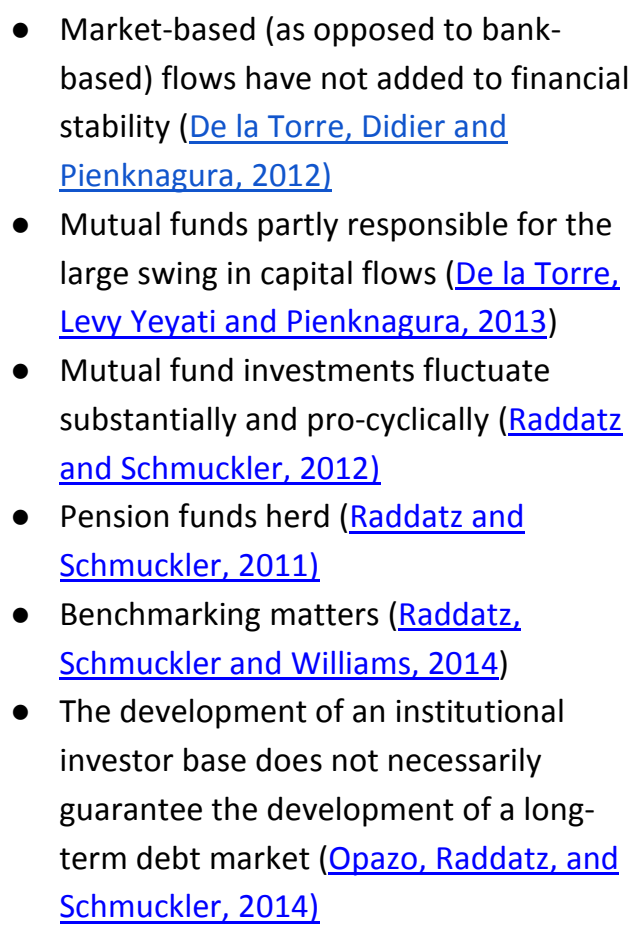 & \\
\hline $\begin{array}{l}\text { FDI less dangerous } \\
\text { than other flows }\end{array}$ & 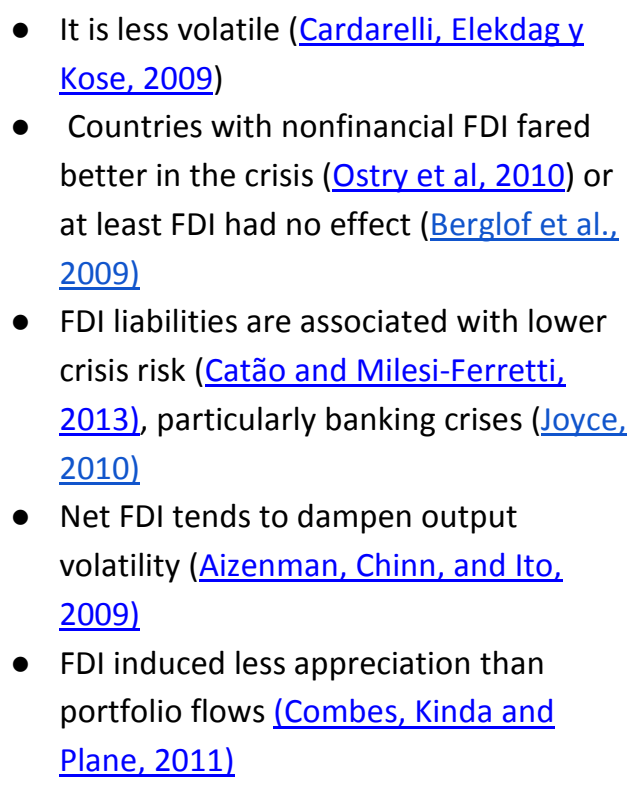 & $\begin{array}{l}\text { Surge in any flow type } \\
\text { increases the risk of a } \\
\text { banking crisis in combination } \\
\text { with lending boom } \\
\text { (Caballero, 2012) }\end{array}$ \\
\hline $\begin{array}{l}\text { Foreign bank } \\
\text { lending is pretty } \\
\text { risky }\end{array}$ & $\begin{array}{l}\text { - Net position vis-à-vis BIS banks had } \\
\text { significant effect on growth downturn } \\
\text { during the crisis (IMF, 2010) and Lane } \\
\text { and Milesi-Ferreti, 2010) } \\
\text { - Increases output volatility (Aizenman, } \\
\text { Chinn, and Ito, 2009) and the probability } \\
\text { of a banking crises (Powell and Tavella, } \\
\text { 2012) }\end{array}$ & $\begin{array}{l}\text { - Negative effect on growth } \\
\text { but less negative than other } \\
\text { debt liabilities (Blanchard, } \\
\text { Faruquee and Das, 2010) } \\
\text { Bank lending from advanced } \\
\text { economies had no significant } \\
\text { effect on unexpected growth } \\
\text { decline in 43EM albeit did }\end{array}$ \\
\hline
\end{tabular}




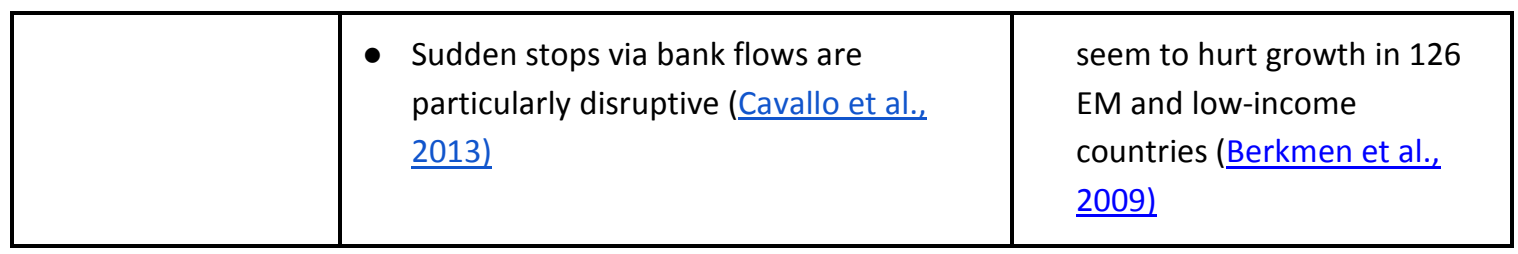

Source: Authors' summary

Finally, an example of how the different behavior of flows may vary depending on the underlying macroeconomic conditions or other influencing factors is provided by Ahmed and Zlate (2013), who model the determinants of net private capital inflows to major emerging markets, based on quarterly panel data set that covers 12 emerging economies from Asia and Latin America over the period Q1 2002 to Q2 2012. In the post-crisis period growth differentials, policy rate differentials, and global risk aversion, appear to be equally important both for total net inflows and portfolio net inflows, while in the pre-crisis period growth differentials were relatively more important for total inflows while risk aversion was relatively more important for portfolio inflows. Rather than an everything-goes conclusion, the study reminds us of the difficulty of characterizing flows with a few broad brushes, or in a predetermined order of riskiness, a temptation that makes for an appealing paper or op. ed. but that ultimately narrows the depth of the policy analysis, more obliged to the local context and initial conditions.

\section{Policy responses: A taxonomy}

While not the center of the present survey, it is useful to complete the previous taxonomy of capital flows with a similar (albeit simpler) taxonomy of policy responses.

It is not surprising that governments have experimented over time with a number of measures to counter either capital flows or their effect on the foreign exchange market and liquidity. Following Cárdenas and Levy Yeyati (2011), the myriad of policies undertaken to deal with the undesired effects of the flows could be bundled in two main categories: buying the inflows and selling the outflows (more generally, "trading the flows", which implies adjusting the public sector foreign currency position to offset the flows) and imposing marginal costs or quantitative limits on flows ("taxing the flows") to complement (and reduce the cost) of trading the flows. Whereas the first type tends to be a general response to inflows regardless of their composition (for example, foreign exchange intervention can strengthen if flows are of a short-term nature but cannot target short-term flows), the second type usually aims at particular, presumably more harmful flows -at least at the outset. However, because of the usual arbitrage problems (for example, short-term flows masquerading as long-term ones) they ultimately become less discriminating, weakening their more specific nature. 
In what follows, we briefly describe the two groups of measures in order.

\section{Trade the flows}

This set of policies consists primarily of traditional intervention by the Central Bank, be it in the form of sterilized dollar purchases in the spot market (whereby the Central Bank "issues" local currency paper in exchange for dollars, changing supply and demand in the foreign exchange market, meeting the demand for local currency assets without altering the money supply) or intervention in the forward market (which has no immediate monetary effect and therefore needs no sterilizing open market operations).

There are also the similar effects that can be achieved by the Treasury through public credit management, that is, balance sheet operations that change the currency composition of the consolidated public debt. And, of course, the same effects, attainable via quasi-sovereign entities.

Whether intervention works, what is works for, at which cost, and under which circumstances, is still a subject of debate. Summarizing the discussion and papers presented at the meeting of Deputy Governors of major EMEs in Basel on 21-22 February 2013, for example, BIS (2014) highlights above all the lack of consensus ${ }^{22}$.

In a substantial fraction of the literature FX intervention is deemed as effective to curb volatility, support market functioning (for example lowering the bid-ask spread in the FX market, as found by García-Verdú y Zerecero, 2013); depreciate the exchange rate (Daude, Levy Yeyati and Nagengast, 2014; Cárdenas and Levy-Yeyati, 2011; Watanabe and Yabu, 2013; Neely, 2011) or at least slow the pace of appreciation (Adler and Tovar, 2011; Blanchard, de Carvalho Filho and Adler, 2014; Menkhoff, 2013), and on occasion even enhance the credibility of the inflation-targeting frameworks (Qureshi et al., $2011)^{23}$. This is all in addition to the works that highlight the merits of reserve accumulation on protective grounds (see for instance Bussiere et al., 2014; Bussiere et al., 2013; Aizenman, Pinto and Sushko, 2013; and Catão and Milesi-Ferretti, 2013).

For those on the skeptical camp, intervention is primarily not effective to moderate real appreciation (e.g., Cardarelli, Elekdag y Kose, 2009) or the effect is small, short-lived (Newman, Potter and Wright, 2011), and potentially detrimental vis-à-vis volatility

\footnotetext{
${ }^{22}$ Villegas and Perez Reina (2015) similarly expose the divide in a recent survey.

23 Interrestingly, Adler and Tovar highlight that the effect of intervention on the exchange rate decreases with the degree of capital account openness and also that intervention is more effective when the exchange rate is already overvalued (Adler and Tovar, 2011). Echavarría et al, (2013) find that intervention is more effective when rule-based.
} 
(Vargas, González, and Rodríguez, 2013) or inflation expectations (Pincheira, 2013). Moreover a non-negligible number of works cast a veil of skepticism over even reserve accumulation, arguing that it has no discernible protective effect (Blanchard, Faruquee and Das (2010) or that it has other adverse consequences such as a crowding-out effect (Reinhart and Tashiro, 2013); a "keeping up with the Jones" effect (Cheung and Qian, 2007; Cheung and Sengupta, 2011); or, at odds with most literature, a negative effect on growth (Llaudes, Salman and Chivakul, 2010).

Even for some of its cheerleaders, intervention can be deemed too costly. This is because the fiscal costs of sterilizing (the sum of the carry plus the valuation changes in the foreign currency position) may be important if interest rate differentials are wide or the local currency ultimately appreciates relative to the foreign currency. However, if differentials are small and the exchange rate pressure is cyclical (that is, if the public sector increases its foreign currency position when the local currency is expensive and reduces it when the local currency is cheap), intervention costs may be small or event turn into a gain (Levy Yeyati, 2010; De la Torre, Levy Yeyati and Pienknagura, 2013). It follows that a relevant and often underemphasized aspect of capital flows is their persistence over time: to what extent a change in the net foreign asset position of the country will be reverted in the near term -certainly a dimension deserving further study.

\section{Tax the flows}

This category includes:

1. The Chilean-type Tobin tax or the equivalent unremunerated reserve requirements on selected foreign inflows ${ }^{24}$

2. Traditional reserve requirements to widen the wedge between the borrowing interest rate that determines the currency carry trade profit, and the lending rate that governs the transmission of monetary policy

3. Although not technically a tax, governments can target the portfolio composition of local investors with Asian-type quantitative caps on cross-border flows and foreign ownership, "micro prudential" measures such as limits to banks' foreign exchange positions and restrictions on dollar lending to non-dollar earners ${ }^{25}$, red tape options like reporting requirements of foreign exchange transactions, and

\footnotetext{
${ }^{24}$ Korineck (2011) highlights in his survey how the constrained optima in several financial crisis models could equivalently be implemented by price or quantity regulations. He argues this is because the existing literature makes strong homogeneity assumptions, for example, there is a "representative" borrower.

${ }^{25}$ Ostry et al (2010) caution that even if prudential regulation were perfectly able to curtail lending booms (including in foreign currency) by domestic banks, there could be a case for curtailing debt liabilities to lower crisis risk because agents may have direct (i.e., not mediated by banks) access to foreign credit and non-financial intermediaries
} 
the lifting of capital restrictions on outflows (as in the relaxation of foreign asset limits to local institutional investors). Likewise, they can impose limits on foreign asset positions on institutional investors (pension funds and insurance companies) or even modify the benchmark against which pension fund performance is measured (which should bias the typical pension fund currency position). Relaxing these limits and taxes and reducing the correlation between the benchmark and the exchange rate should partially offset capital inflows, and vice versa.

Whereas capital control enthusiasts used to be a rare species a few years ago, they are handsomely represented in the recent literature. Though relatively few of them find capital controls to be effective to affect the volume of flows (exceptions include Forbes, Fratzscher, and Kostka, 2011; Levy Yeyati, 2011), quite a few find them effective to alter their composition (Jankov and Banka, 2009; Magud, Reinhart and Rogoff, 2011; Binici et $\underline{\text { al, } 2009}$ and references therein); tilting flows toward longer maturities (Habermeier, Kokenyne, and Baba, 2011) and away from FX borrowing (Qureshi et al, 2011; Clemens and Kamil, 2009) and generally debt liabilities (Ostry et al, 2010 and references therein; IMF 2010; Qureshi et al, 2011), especially when controls are long-standing (Klein, 2012). Magud, Reinhart and Rogoff (2011) also note controls can make monetary policy more independent.

Some detractors, meanwhile, criticize capital controls for being easy to circumvent (Spiegel, 2012); useless to discourage inflows (Baba and Kokenyne, 2011; Jinjarak, Noy and Zheng, 2013) or alter their composition_Concha, Galindo and Vazquez, 2011); and ineffective to moderate real appreciation (Cardarelli, Elekdag y Kose, 2009; Baba and Kokenyne, 2011), reduce vulnerability (Cardarelli, Elekdag y Kose (2009) or the probability of a sudden stop (Cifuentes and Jara, 2014), and alter a series of variables including equity indices, inflation, interest-rate differentials, the volatility of the exchange rates, portfolio flows, or interest rate differentials (Forbes, Fratzscher and Kotska, 2011). In the worst case, moreover, they may increase inflation and output volatility (Fratzscher, 2012) and have an adverse effect on financial intermediation and the cost of capital ${ }^{26}$.

Finally a few works fall into the "it depends" camp, stressing the effectiveness of combining instruments (Rincón and Toro (2010) or the need to heed the circumstances under which capital controls are applied (Baba and Kokenyne, 2011; Cardarelli, Elekdag and Kose, 2009)

${ }^{26}$ Capital controls may also have unexpected multilateral effects (see Pasricha et al. 2015) 
Macro prudential measures, in turn, have a growing fan club (Magud and Tsounta, 2012; Ostry et al, 2010). Reserve requirements, in particular, have recently elicited praise for influencing market rates while moderating capital flows (Montoro and Moreno, 2011) and even depreciating the exchange rate (Glocker and Towbin, 2012). On the other hand, Cordella et al. (2014) caution about the conflicts that may arise between the micro- and macro-prudential policy stances.

\section{Mainstream policies}

Conventional wisdom from mainstream economics tends to depict both types of the policy responses discussed above as last-resort or complementary to the more traditional fiscal policy and prudential regulation as tools to mitigate overvaluation and deflate potentially risky booms and bubbles (e.g., Ostry et al, 2010). Along the same lines, Cavallo and Izquierdo (2008) highlight how the flexibility to implement expansionary policies during a sudden stop pays handsomely in terms of a smaller recession and lower output volatility.

On the other hand, beyond these two direct response categories, there are a set of macroeconomic best practices that governments could have in place to avoid the negative effects of flows of these reversals. For example, De la Torre, Levy Yeyati and Pienknagura (2013) call for an "improved macro-financial immune system", that is, gradual but steady financial de-dollarization and the consolidation of credible inflationtargeting regimes that can reduce (and have reduced) significantly the exchange rate pass- through and thereby the fear of floating ${ }^{27}$. Berkmen et al. (2009) also highlight that exchange-rate flexibility helped in buffering the impact of the global financial crisis, particularly for emerging markets ${ }^{28}$. This is also consistent with the results of Blanchard, Faruquee and Das (2010), who find that countries with a fixed exchange rate regime saw unexpected declines in output during the crisis of $18.6 \%$ compared with $11.3 \%$ in countries with flexible regimes ${ }^{29}$. And Because it is easy to circumvent capital controls, especially in developed economies, Spiegel (2012) suggests markets should give regulators more tools (such as clearing houses) to monitor flows and dynamically design

\footnotetext{
27 The authors argue that letting the currency depreciate can mitigate capital outflows, by quickly adjusting the relative values of foreign and domestic assets and thereby promoting "bargain hunting" inflows.

${ }^{28}$ They also find evidence that countries with a stronger fiscal position prior to the crisis were impacted less severely and little evidence for the importance of other policy variables

${ }^{29}$ Controlling for trade and short-term debt, they find that countries with fixed exchange rate regimes had $2.7 \%$ lower growth during the crisis.
} 
interventions.

In addition, policy responses at the country level could be complemented by global policies and a better international financial architecture. For example, Fernández Arias and Levy Yeyati (2012) and Lane (2013) call for a stronger international safety net (under the auspices of the IMF) to insure countries against globally induced capital account reversals. Other global aspects of the capital flow problem include the need for regulation to limit the too big to fail problem (the fact that the risk if systemically important financial institutions are ultimately socialized by publicly funded bailout schemes), or to enhance bank capital structures to provide a sufficient buffer against unexpectedly large losses. An over-reliance on debt financing could be further corrected by reforms in taxation and corporate governance systems to limit the current incentives to prefer debt funding over equity funding. While such reforms could in principle be done at the national level, the cross-border spillover effects in relation to the taxation and regulation of corporations and mobile factors mean that, in practice, international cooperation is an inevitable condition.

\section{What do we know? What do we need to know?}

The previous survey concentrated in the recent literature on capital flows, with a focus on the distinction between different varieties of flows by the new wave of research triggered by the recent global financial crisis. We can divide the literature into two big groups of papers: those that based their tests on long samples covering most of the post-Bretton Woods periods and those zooming in on the event of the global crisis to identify and attribute differential responses according to each country's exposure to different types of flows.

The first group trades sample size and precision for accuracy: most of these papers examine financial crises that plagued the developing world up till the early 2000s perhaps the reason why they need to go back in the sample selection. As such, the findings may be more informative about past exposures (for example, the well-known association between inflows and financial dollarization and currency mismatches coupled with the currency pegs of the 1980s and 1990s) than they are about the present (as the share of flows applied to foreign currency-denominated fixed income vehicles, as well as the propensity to build up large exchange rate misalignments under a peg have been gradually fading). That said, it is because of those learned lessons that some of the warnings from the past are no longer dominating concerns. The key question regarding those studies is to what extent those effects are replicated in shorter and more recent 
data -and, if not, what are the conditions under which those effects may reappear.

The second groups of studies is subject to a complementary caveat: they usually adopt a pseudo-event study approach and look a cross section of economies before and after the global crisis and correlate the variable of interest (output drop, growth deceleration, exchange rate correction) with a number of potentially relevant variables including size and composition of inflows and foreign exposures. Predictably, the results tend to be consistent and somewhat erratic (particularly, when country samples are refined or controls are multiplied, at the expense of precision). Here, the key question is about generality: to what extent the findings associated with a global financial and real crisis can be extended to more local financial shocks? In particular, to what degree can we attribute to financial flows the consequences of an event that conflated a financial panic with a collapse in global demand and trade?

In sum, although we know quite a lot, in practical terms (those that should inform policy) we may know rather less than we thought. Some of the knowledge is outdated, and some is possibly hampered by various problems of colinearity, missing variables and model misspecification.

Last but not least, there is the question about data. As noted, BOP figures may not be the best record of actual flows coming in and out of the economy (particularly when it comes to FDI). Moreover, some of the relevant cuts (most notably, resident vs. nonresident holders) are close to impossible to trace. Greater granularity of data is needed to confirm whether the conventional wisdom risk order of individual capital flows is validated in reality -as a first step to customize policy responses when needed. 


\section{References}

Adler, G. and C. Tovar (2011) "Foreign Exchange Intervention: A Shield Against Appreciation Winds?" IMF Working Paper \#11/165.

Ahmed, S. and A. Zlate (2013) "Capital Flows to Emerging Market Economies: A Brave New World?" The Federal Reserve Board International Finance Discussion Papers.

Ahrend, R. and A. Goujard (2012) "International Capital Mobility and Financial Fragility Part 1. Drivers of Systemic Banking Crises: The Role of Bank-Balance-Sheet Contagion and Financial Account Structure". OECD Economics Department Working Paper 902.

Ainzenman, J., M. Chinn, and H. Ito (2009) "The Emerging Global Financial Architecture: Tracing and Evaluating New Patterns of the Trilemma Configuration" Journal of International Money and Finance, Vol. 29, No. 4, p. 615-641 (2010).

Aizenman, J., M. Hutchinson and I. Noy (2008) "Inflation Targeting and Real Exchange Rates in Emerging Markets" NBER Working Paper No. 14561.

Aizenman, J. B. Pinto and V. Sushko (2013) "Financial sector ups and downs and the real sector in the open economy: Up by the stairs, down by the parachute" BIS Working Paper 411.

Baba, C. and A. Kokenyne (2011) "Effectiveness of Capital Controls in Selected Emerging Markets in the 2000s" IMF Working Paper 11/281

Bank for International Settlements (2013) "Market volatility and foreign exchange intervention in EMEs: what has changed?" BIS papers \#73.

Berglof, E., Y. Korniyenko, A. Plekhanov, and J. Zettelmeyer (2009) "Understanding the Crisis in Emerging Europe" European Bank for Reconstruction and Development Working Paper \#109.

Berkmen, P., G. Gelos, R. Rennhack, and J. P. Walsh (2009) "The Global Financial Crisis: Explaining Cross-Country Differences in the Output Impact" IMF Working Paper \#9/280.

Binici, M., M. Hutchinson and M. Schindler (2009) "Controlling Capital? Legal Restrictions and the Asset Composition of International Financial Flows" IMF Working 
Paper \#09/208.

Blanchard, O., I. de Carvalho Filho and G. Adler (2014) "Can Sterilized Foreign Exchange Intervention Stem Exchange Rate Pressures from the Global Financial Cycle?" IMF.

Blanchard, O., H. Faruqee and M. Das (2010) "The Initial Impact of the Crisis on Emerging Market Countries" Brookings Papers on Economic Activity.

Bordo, M., C. Meissner and D. Stuckler (2009) "Foreign Currency Debt, Financial Crises And Economic Growth: A Long Run View" National Bureau of Economic Research Working Paper \#15534.

Bussiere, M, G. Cheng, M. Chinn, and N. Lissack (2013) "Capital Controls and Foreign Reserve Accumulation: Substitutes or Complements in the Global Financial Crisis?

Bussiere, M, G. Cheng, M. Chinn, and N. Lissack (2014) "For a Few Dollars More: Reserves and Growth in Times of Crises" NBER Working Papers 19791, National Bureau of Economic Research, Inc.

Caballero, J. (2012) "Do Surges in International Capital Inflows Influence the Likelihood of Banking Crises? Cross-country Evidence on Bonanzas in Capital Inflows and BonanzaBoom-Bust Cycles" IDB Working Paper \#305.

Calvo, G., A. Izquierdo and R. Loo-Kung (2012) "Optimal Holdings of international Reserves: Self-Insurance Against Sudden Stops" NBER Working Paper \#18219.

Cardarelli, R., S. Elekdag and A. Kose (2009) "Capital Inflows: Macroeconomic Implications and Policy Responses". IMF Working Paper 09/40.

Cardenas, M. and E. Levy-Yeyati (2011) "Latin America Economic Perspectives: Shifting Gears in an Age of Heightened Expectations" Brookings April 2011 Report

Catao, L. and G. Milesi-Ferretti (2013) "External Liabilities and Crises" IMF Working Paper \#13/113.

Cavallo, E. and A. Izquierdo, eds. (2009) "Dealing with an International Credit Crunch: Policy Responses to Sudden Stops in Latin America" IDB, Washington, DC. 
Cavallo, E., A. Powell, M. Pedemonte and P. Tavella (2013) "A New Taxonomy of Sudden Stops: Which Sudden Stops Should Countries Be Most Concerned About?" IDB Working Paper \#430.

Cheung, Y. and X. Qian (2007) “Hoarding of International Reserves: Mrs Machlup's Wardrobe and the Joneses" CESifo Working Paper Series with number 2065

Cheung, Y. and R. Sengupta (2011) "Accumulation of reserves and keeping up with the Joneses: The case of LATAM economies" International Review of Economics \& Finance. Vol. 20 Issue: 1 Pages: 19-31

Cifuentes, R. and Al. Jara (2014) "Facing Volatile Capital Flows: The Role of Exchange Rate Flexibility and Foreign Assets" Documento de trabajo número 742, Banco Central de Chile.

Clemens, B. and H. Kamil (2009) "Are Capital Controls Effective in the 21st Century? The Recent Experience of Colombia" IMF Working Paper \#09/30.

Combes, J., P. Plane and T. Kinda (2011) "Capital Flows, Exchange Rate Flexibility, and the Real Exchange Rate" IMF Working Paper \#11/9.

Concha, A., A. Galindo, and D. Vasquez (2011) "An Assessment of Another Decade of Capital Controls in Colombia: 1998-2008" Electronic copy available at: http://ssrn.com/abstract=1201878

Cordella, T. P. Federico, C. Vegh and G. Vuletin (2014) "Reserve Requirements in the Brave New Macroprudential World" Washington, D.C., World Bank Studies.

Corsetti, G. (2010) “The 'original sin' in the Eurozone” VOX EU, May 9.

Daude, C. E. Levy Yeyati and A. Nagengast (2014) "On the Effectiveness of Exchange Rate Interventions in Emerging Markets" OECD Development Center Working Papers 324, OECD Publishing.

De Grauwe, P. (2011) “The governance of a fragile Eurozone” CEPS working documents.

De la Torre, A., E. Levy Yeyati and S. Pienknagura (2013) "Latin America's Deceleration and the Exchange Rate Buffer." LAC Semiannual Report (October), World Bank, 
Washington, DC. doi:10.1596/978-1-4648-0115-0 License: Creative Commons Attribution CC BY 3.0.

De la Torre, A., T. Didier and Pienknagura (2012) "Latin America Copes with Volatility: The Dark Side of Globalization" World Bank Latin America and Caribbean Semi-Annual Report.

Dell'Erba S., R. Hausmann, and U. Panizza (2013) “Debt Levels, Debt Composition, and Sovereign Spreads in Emerging and Advanced Economies" CID Working Paper \#263.

Du, W. and J. Schreger (2013) "Local Currency Sovereign Risk" Board of Governors of the Federal Reserve System International Finance Discussion Papers \#1094

Forbes K. and F. Warnock (2012) "Debt and Equity Led Capital Flow Episodes" NBER Working Paper 18329.

Forbes, K. and F. Warnock (2011) "Capital Flow Waves: Surges, Stops, Flight and Retrenchment" NBER Working Paper 17351.

Forbes, K. M. Fratzscher and T. Kostka (2011) “Bubble Thy Neighbor: Direct and Spillover Effects of Capital Controls" Paper presented at the 12th Jacques Polak Annual Research Conference. Hosted by the International Monetary Fund. Washington, DC-November $10-11,2011$

Fratzscher, M. (2012) "Capital Controls And Foreign Exchange Policy" European Central Bank Working Paper \#1415.

Gallagher, K., S. Griffith-Jones and J. Ocampo (2012) "Regulating Global Capital Flows for Long-Run Development" Pardee Center Task Force Report.

García-Verdú, S. and M. Zerecero (2013) "On central bank interventions in the Mexican peso/dollar foreign exchange market," BIS Working Papers 429, Bank for International Settlements.

Glocker, C. and P. Towbin (2012) "The Macroeconomic Effects of Reserve Requirements" WIFO Working Papers number 420.

Gourinchas, P. and Obstfeld, M. (2012). "Stories of the Twentieth Century for the 
Twenty-First". American Economic Journal: Macroeconomics, 4(1):226-65

Habermeier, K., A. Kokenyne, and C. Baba (2011) "The Effectiveness of Capital Controls and Prudential Policies in Managing Large Inflows" IMF Discussion Note 11/14.

Hausmann, R. and U. Panizza (2010) "Redemption or Abstinence? Original Sin, Currency Mismatches and Counter-Cyclical Policies in the New Millennium" CID Working Paper \#194

IADB (2014) "Global Recovery and Monetary Normalization Escaping a Chronicle Foretold?" Latin American and Caribbean Macroeconomic Report.

IMF (2010) "How Did Emerging Markets Cope in the Crisis?" Prepared by the Strategy, Policy, and Review Department.

Jácome, L., E. W. Nier, and P. Imam (2012) "Building Blocks for Effective Macroprudential Policies in Latin America: Institutional Considerations" IMF Working Paper \#12/183.

Jankov, L. and H. Banka (2009) "Spillovers of the Crisis: How Different Is Croatia?" Proceedings of OeNB Workshops.

Jinjarak, Y., I. Noy and H. Zheng (2013) "Capital Controls in Brazil - Stemming a Tide with a Signal?” Journal of Banking \& Finance, Elsevier, vol. 37(8), pages 2938-2952.

Joyce, J. (2009) "Financial Globalization and Banking Crises In Emerging Markets" Open Economics Review, Vol. 22. P 875-895.

Lane, P. (2013) "Capital Flows in the Euro Area" European Economy - Economic Papers 497, Directorate General Economic and Monetary Affairs (DG ECFIN), European Commission.

Klein, M. (2012) “Capital Controls: Gates versus Walls” NBER Working Paper No. 18526

Korineck, A. (2011) "The New Economics of Prudential Capital Controls: A Research Agenda". IMF Economic Review, Vol. 59, Issue 3, pp. 523-561, 2011

Lane, P. and G. Milesi-Ferretti (2010) "The Cross-Country Incidence of the Global Crisis" IMF Working Paper \#10/171. 
Lane P. (2013) "Capital Flows in the Euro Area" European Economy - Economic Papers 497, Directorate General Economic and Financial Affairs (DG ECFIN), European Commission.

Levy Yeyati, E. (2005) "Financial Dollarization: Evaluating the Consequences" Universidad Torcuato Di Tella Business School Working Papers

Levy Yeyati, E. (2010) "What drives reserve accumulation (and at what cost)?" voxeu.org.

Llaudes, R., F. Salman, and M. Chivakul (2010) "The Impact of the Great Recession on Emerging Markets" IMF Working Paper 10/237.

Magud, N. C. Reinhart and K. Rogoff (2011) "Capital Controls: Myth And Reality - A Portfolio Balance Approach" NBER Working Paper \#16805.

Magud, N. and E. Tsounta (2012) "To Cut or Not to Cut? That is the (Central Bank's) Question" IMF Working Paper number 12/243.

Neely, C. (2011) "A Foreign Exchange Intervention in an Era of Restraint" Federal Reserve Bank of St. Louis Review, Pages 303-324.

Newman, V., C. Potter and M. Wright (2011) "Foreign Exchange Market Intervention" Reserva Bank of Australia Bulletin - December Quarter 2011

Obstfeld, M., J. Shambaugh and A. Taylor (2008) "Financial Stability, the Trilemma, and International Reserves" NBER Working Paper \#14217.

Opazo, L., C. Raddatz and S. Schmuckler (2014) "Institutional Investors and Long-term investments" World Bank Policy Research Paper number 6922

Ostry, J. A. Ghosh, K. Habermeier, M. Chamon, M. Qureshi, and D. Reinhardt (2010) "Capital Inflows: the Role of Controls" IMF Position Note.

Pasricha, G., M. Falagiarda, M. Bijsterbosch, and J. Aizenman (2015) "Domestic and Multilateral Effects of Capital Controls in Emerging Markets" NBER Working Paper \#20822 
Pincheira, Pablo (2013) "Interventions and Inflation Expectations in an Inflation Targeting Economy" Banco Central de Chile Working Papers 693

Powell, A., and P. Tavella (2012) "Capital Inflow Surges in Emerging Economies: How Worried Should LAC Be?" IDB Working Paper \#326

Qureshi, M., J. Ostry, A. Ghosh, and M. Chamon (2011) "Managing Capital Inflows: The Role of Capital Controls and Prudential Policies" NBER Working Paper number 17363.

Raddatz, C. and S. Schmuckler (2011) "Deconstructing herding : evidence from pension fund investment behavior" World Bank Policy Research Paper number 5700

Raddatz, C. and S. Schmuckler (2012) "On the international transmission of shocks: micro-evidence from mutual fund portfolios" World Bank Public Policy Research Paper number 6072

Raddatz, C., S. Schmuckler and T. Williams (2014) "International asset allocations and capital flows: the benchmark effect" World Bank Policy Research Working Paper number 6866

Reinhart, C. and T. Tashiro (2013) "Crowding Out Redefined: The Role of Reserve Accumulation" NBER Working Paper No. 19652.

Spiegel, S. (2012) "How to Evade Capital Controls...and Why They Can Still Be Effective" in Gallagher, K., S. Griffith-Jones and J. Ocampo (2012) "Regulating Global Capital Flows for Long-Run Development" Pardee Center Task Force Report.

Vargas, H., A. González y D. Rodríguez (2013) "Foreign Exchange Intervention in Colombia" Banco de la República de Colombia Borradores de Economía número 757.

Villegas, M. and D. Perez Reina (2015) "A Survey on the Effects of Sterilized Foreign Exchange Intervention" Borradores de economía \#862, Banco de la República de Colombia.

Watanabe, T. and Y Tomoyoshi (2013) "The great intervention and massive money injection: The Japanese experience 2003-2004" Journal of International Money and Finance. Vol: 32 -C,? Pages: 428-443 